\title{
Kesepian Remaja Pada Masa Pandemi COVID-19
}

\section{Dony Darma Sagita ${ }^{* 1}$, Dede Hermawan ${ }^{2}$}

1,2Program Studi Bimbingan dan Konseling, Universitas Muhammadiyah Prof. DR. HAMKA, Jakarta, Indonesia.

*)1Corresponding author, Đe-mail: donyds@uhamka.ac.id

$\begin{array}{lcc}\text { Received: } & \text { Accepted: } & \text { Published: } \\ \text { August 2020 } & \text { 02 November 2020 } & \text { 29 December 2020 }\end{array}$

\begin{abstract}
The COVID-19 pandemic is a complex problem in the life of Indonesian society today, including aspects of individual personality. The purpose of this study was to empirically examine the level of adolescent loneliness during the COVID-19 pandemic. This study used quantitative method research with a descriptive approach. The sample were 300 adolescents that selected by convenience sampling technique. The results showed that the level of loneliness of adolescents during the COVID19 pandemic was in a quite high category with a proportion of $43 \%, 10 \%$ in high category, and $1,7 \%$ in very high category. It means the adolescent need to be more attention so that teenagers can lead a normal life in their daily lives.
\end{abstract}

Keywords: Loneliness, Adolescent, The COVID-19 Pandemic

\begin{abstract}
Abstrak
Pandemi COVID-19 menjadi permasalahan yang kompleks dalam kehidupan masyarakat indonesia hari ini termasuk aspek kepribadian individu. Tujuan kajian ini adalah untuk menguji secara empiris tingkat kesepian remaja pada masa pandemi COVID-19. Penelitian ini menggunakan pendekatan deskriptif kuantitatif. Jumlah sampel dalam penelitian ini adalah 300 remaja dengan menggunakan teknik convenience sampling. Hasil penelitian ini menunjukan tingkat kesepian remaja di masa pandemi COVID-19 ini berada pada kategori cukup tinggi dengan persentase $43 \%, 10 \%$ pada kategori tinggi dan $1,7 \%$ pada kategori sangat tinggi. Hal ini menunjukan perlunya perhatian yang lebih terhadap remaja supaya remaja bisa menjalankan kehidupan secara normal dalam kesehariannya.
\end{abstract}

Kata Kunci: Kesepian; Remaja; Pandemi COVID-19

How to Cite: Sagita, D. D., \& Hermawan, D. (2020). Kesepian Ramaja Pada Masa Pandemi COVID19. ENLIGHTEN: Jurnal Bimbingan Konseling Islam, 3(2), 122-130.

https://doi.org/10.32505/enlighten.v3i1.1892

This is an open access article distributed under the Creative Commons Attribution License, which permits unrestricted use, distribution, and reproduction in any medium, provided the original work is properly cited. (C)2020 by author.

\section{PENDAHULUAN}

Coronavirus Disease 2019 (COVID-

19) dengan cepat menyebar secara global menginfeksi manusia dengan jumlah kasus terkonfirmasi lebih dari 13 juta kasus di 188 negara (Johns Hopkins University \& Medicine, 2020). Akhirnya, World Health Organization (WHO) pada 11 Maret 2020 menetapkan secara resmi COVID-19 sebagai pandemi (Friana, 2020). Semakin cepatnya sebaran virus, WHO (2020) mendorong masyarakat dunia untuk melakukan berbagai upaya memotong rantai sebaran virus. Salah satunya dengan melakukan physical distancing. Physical distancing merupakan istilah untuk menjaga jarak fisik sesuai dengan protokol kesehatan untuk meminimalisir 
penyebaran virus tidak semakin meluas (Putsanra, 2020).

Pemerintah di berbagai negara dengan cepat telah menerapkan berbagai kebijakan yang belum pernah dilakukan sebelumnya. Termasuk kebijakan Pembatasan Sosial Berskala Besar (PSBB) di Indonesia (Menteri Kesehatan Republik Indonesia, 2020). PSBB merupakan kebijakan yang dilakukan pemerintah untuk menekan laju penyebaran COVID-19 agar tidak semakin meluas dengan membatasi aktivitas luar rumah. PSBB pertama kali diberlakukan di DKI Jakarta (Mushabi, 2020) sebagai salah satu provinsi dengan tingkat kasus COVID-19 tertinggi di Indonesia.

Akibatnya, COVID-19 telah memaksa berbagai kegiatan yang awalnya mempertemukan banyak orang kini telah berubah, seperti pembelajaran sekolah yang awalnya dilakukan secara tatap muka beralih secara daring, para pekerja menjadi bekerja dari rumah, maupun pelaksanaan ibadah yang dilaksanakan di rumah. Oleh karena itu, pandemi ini sangat berdampak pada perubahan dan terbatasnya kontak sosial secara fisik. Ditambah dengan diberlakukannya PSBB (Pembatasan Sosial Berskala Besar), individu terpaksa menghabiskan waktu sepanjang hari di tempat tinggal masing-masing dalam waktu yang cukup lama. Keadaan ini dapat membuat individu kehilangan kebersamaan dengan sahabat, timbulnya kebosanan, kehilangan semangat maupun kegembiraan. Situasi ini memunculkan kecemasan akan berdampak pada meningkatnya kesepian (Holmes et al., 2020).
Kesepian terjadi sebagai reaksi individu terhadap situasi sosial (Sønderby \& Wagoner, 2013). Meski kesepian dikaitkan dengan hubungan sosial yang objektif, para ahli sepakat bahwa kesepian merupakan pengalaman subjektif (Cosan, 2014; Sønderby \& Wagoner, 2013). Artinya, kesepian bukan sesuatu yang dapat diukur dengan jumlah kedekatan secara fisik. Orang bisa merasakan kesepian meski berada dalam keramaian dan tidak merasa kesepian meski sendirian. Namun, kesepian terjadi ketika individu menghadapi situasi kontradiksi dimana jumlah hubungan yang ada lebih kecil dari yang diharapkan serta keintiman yang diinginkan belum terwujud (Cosan, 2014; Gierveld, Tilburg, \& Dykstra, 2006; Sønderby \& Wagoner, 2013). Oleh karena itu, situasi pandemi hari ini dapat menimbulkan kerinduan pada banyak orang untuk bertemu sementara di sisi lain munculnya kekhawatiran akan adanya virus serta banyaknya batasan aktivitas luar rumah. Kesepian menjadi sangat mungkin dirasakan.

Sejauh ini, kesepian sudah menjadi fenomena universal (Mushtaq, Shoib, Shah, \& Mushtaq, 2014) artinya kesepian dapat dialami oleh semua orang terlepas dari perbedaan usia, gender, budaya maupun agama. Sebagian besar penelitian abad ke20 menunjukan tingkat kesepian mengikuti lintasan berbentuk $U$, tinggi pada masa remaja, menurun pada usia dewasa menengah dan mengalami peningkatan pada usia tua (Victor \& Yang, 2012). Didukung temuan terbaru bahwa usia muda melaporkan kesepian yang lebih intens dibandingkan usia lainnya (Barreto 
et al., 2020; Hammond, 2018). Adanya bukti-bukti ini memberikan gambaran bahwa remaja akan lebih rentan merasakan kesepian ketika dihadapkan pada situasi yang lebih kontekstual seperti akibat penyebaran virus COVID-19 saat ini.

Bagaimanapun juga, kesepian tidak hanya menimbulkan perasaan menyakitkan bagi yang mengalaminya. Namun, kesepian dalam banyak penelitian ditemukan berkaitan dengan munculnya gangguan psikis lain hingga gangguan fisik. Di antaranya Cacioppo, Hughes, Waite, Hawkley, \& Thisted (2006) menemukan kesepian sebagai prediktor munculnya depresi. Kesepian juga menjadi indikator utama kesejahteraan sosial, penyebab timbulnya gangguan fisik seperti diabetes, obesitas serta penuaan fisiologis (Mushtaq et al., 2014). Berdasarkan argumentasi teoritik di atas, peneliti tertarik untuk melakukan penelitian lebih lanjut mengenai kesepian remaja pada masa pandemi COVID-19 di DKI Jakarta.

\section{METODE}

Penelitian ini merupakan penelitian kuantitatif dengan menggunakan desain survei. Teknik pengambilan sampel menggunakan sampling convenience. Penelitian ini melibatkan 300 partisipan yang dijangkau melalui kuesioner daring dimulai dari 9 Juni hingga 4 Juli 2020. Kuesioner disebar selain mencakup skala kesepian juga berisi informed content dan identitas partisipan. Selain itu, disebutkan kriteria partisipan yaitu: (1) individu yang berusia antara 13-25 tahun berdasarkan usia remaja menurut Badan Kependudukan dan Keluarga Berencana (BKKBN); (2) tinggal di rumah selama pandemic; dan (3) berdomisili di DKI Jakarta.

Rerata usia partisipan adalah 16,69 tahun $(S D=3,286)$. Mayoritas partisipan adalah perempuan sebanyak 230 orang (76,6\%) dan laki-laki 70 orang (23,3\%). Partisipan umumnya berdomisili di Jakarta Timur 137 orang, diikuti oleh Jakarta Barat 84 orang, Jakarta Pusat 48 orang, Jakarta Utara 27 orang dan Jakarta Selatan 4 orang. Mayoritas partisipan tinggal di rumah bersama keluarga dengan rerata anggota keluarga di rumah 4,57 orang $(S D=1,530)$.

Kesepian pada penelitian ini diukur dengan Pandemic Loneliness Scale yang dikembangkan oleh peneliti. Skala ini mengacu pada tipologi kesepian yang dikemukakan oleh Weiss (1973) sebagaimana dikutip dalam Perlman dan Peplau (1984). Skala ini terdiri dari 16 item dengan menggunakan skala Likert sebagai alternatif respon jawaban mulai sangat tidak sesuai sampai sangat sesuai dengan rentang skor 1-4. Koefisien validitas item valid berupa corrected item-total correlation berada pada rentang mulai 0,253 hingga 0,784. Koefisien Alpha Cronbach sebesar 0,846 yang termasuk pada kategori reliabilitas tinggi.

Teknik analisis utama penelitian ini menggunakan teknik analisis deskriptif. Tahap pertama, membandingkan mean hipotetik dan mean empirik, dilanjutkan mendeskripsikan partisipan pada kategorisasi yang mengacu pada model distribusi normal (statistik hipotetik) (Azwar, 2019). Adapun aplikasi yang digunakan untuk pengolahan data yaitu IBM SPSS Statistics 25. 


\section{HASIL TEMUAN}

Berikut ini deskripsi data hasil penelitian mengenai kasepian remaja pada masa pandemi.

Tabel 1. Perbandingan Mean Empirik dan Mean Hipotetik

\begin{tabular}{ccccc}
\hline \multirow{2}{*}{ Variabel } & \multicolumn{4}{c}{ Hipotetik } \\
\cline { 2 - 5 } & Min & Maks & Mean & SD \\
\hline Kesepian & 16 & 64 & 40 & 8 \\
\hline
\end{tabular}

Tabel 2. Distribusi Frekuensi dan Persentase Kesepian

\begin{tabular}{cccc}
\hline Interval Skor & Kategori & Frekuensi & $\mathbf{\%}$ \\
\hline 52 & Sangat Tinggi & 5 & 1.7 \\
$45-52$ & Tinggi & 30 & 10 \\
$37-44$ & Cukup tinggi & 129 & 43 \\
$29-36$ & Rendah & 116 & 38,7 \\
$\leq 28$ & Sangat Rendah & 20 & 6,7 \\
& Total & 300 & 100 \\
\hline
\end{tabular}

Hasil penelitian menunjukan kesepian remaja pada penelitian ini berada pada kategori cukup tinggi, hal ini terlihat dari tabel 2 dengan nilai mean $43 \%$, rendah $38,7 \%$, tinggi $10 \%$, sangat rendah $6,7 \%$ dan dan sangat tinggi pada kategori 6,7\%. Hal ini menunjukan bahwa remaja membutuhkan perhatian dari lingkungan sekitar dalam menghindari terjadinya permasalahan kesepian pada remaja.

\section{PEMBAHASAN}

Hasil temuan dari penelitian ini adalah untuk menjawab tujuan penelitian ini meneliti sejauh kesepian dirasakan remaja, berkaitan dengan adanya pandemi COVID-19 yang mengakibatkan dilakukannya physical distancing hingga Pembatasan Sosial Berskala Besar (PSBB). Berdasarkan hal tersebut, maka di masa awal meluasnya wabah COVID-19 muncul kekhawatiran yang signifikan bahwa jarak sosial akan mengakibatkan meningkatnya kesepian (Fiorillo \& Gorwood, 2020).

Ketika seseorang mengalami gangguan kesepian, seringkali mengalami kesulitan dalam mengendalikan perilaku dan sikap karena pikiran dan perasaannya terpusat pada kesepian yang sedang di hadapinya. Beberapa kasus yang ditemukan di lapangan kesepian itu terjadi karena ketidakmampuan individu dalam mereaksi dan merespon stimulus yang datang dari perasaan dan pikirannya. Seringkali individu meresponnya dengan sikap yang sebaliknya sehingga tidak mampu bersikap positif dan memberikan respon positif juga kepada stimulus yang datang. Akibat dari ketidakmampuannya ini, remaja sulit mengenali masalah utama yang terjadi dalam dirinya, dan menganggap orang lain atau 
lingkungannya sebagai penyebab masalah yang ia alami.

Kesepian merupakan kondisi yang tidak dapat dipisahkan dari setiap aspek kehidupan. Kesepian merupakan sebuah bentuk permasalahan emosional yang bisa saja dialami oleh semua orang dengan kadar berat ringan yang berbeda antarindividu tersebut. Kesepian merupakan kejadian yang berkembang dari persepsi seseorang terhadap kemampuan diri dalam merespon sebuah situasi atau peristiwa. Remaja yang mengalami kesepian senantiasa bersifat subjektif pada setiap remaja. Oleh karena itu, remaja dapat merasa kondisi emosi berbeda dengan yang lain walaupun mengalami kejadian yang sama namun respon yang berbeda.

Hasil riset ini, konsisten dengan temuan terbaru yang dipublikasikan terkait konsekuensi pandemi terhadap kesepian (Luchetti et al., 2020; Tull et al., 2020). Studi Luchetti et al., (2020) terhadap kelompok beresiko di Amerika menunjukan tidak terjadi peningkatan kesepian meski dilakukan karantina, dibandingkan dengan tingkat kesepian sebelum pandemi. Dipertegas dengan temuan Tull et al., (2020) melalui survei cross sectional, kendati dikaitkan dengan perintah tinggal di rumah tetapi dampak COVID-19 dikaitkan negatif dengan kesepian.

Luchetti et al., (2020) berpandangan bahwa hal ini dimungkinkan karena individu, keluarga dan komunitas masih dapat terhubung secara emosional meski jaraknya jauh. Salah satunya, berkat berkembangnya teknologi yang telah menjembatani banyak orang untuk tetap saling berkomunikasi. Terlepas dari jarak secara fisik bukan berarti terputus. Hubungan secara rutin seperti mengirim pesan, mengobrol, saling menyemangati bahkan saling melepas kerinduan tetap dapat dilakukan seperti melalui video call, bertelepon ataupun chatting. Hal ini didukung dengan data melonjaknya penggunaan Whatsapp sebesar $51 \%$ pada masa pandemi ini (WANTIKNAS, 2020). Mengingat Whatsapp merupakan salah satu media komunikasi terpopular di Indonesia.

Di samping itu, kondisi meluasnya wabah telah memperlihatkan kepedulian sosial banyak orang. Termasuk besarnya intervensi pemerintah untuk mengurangi dampak yang lebih buruk dari adanya pandemi. Sesuai pengalaman pada masa lalu bahwa kohesi sosial dan kebersamaan meningkat sejalan dengan dilakukannya karantina (Courtet, Olié, Debien, \& Vaiva, 2020). Studi Zhang \& Ma (2020) membuktikan hal itu, dibalik kekhawatiran COVID-19 yang semakin meluas tetapi mayoritas partisipan merasakan peningkatan dukungan sosial dan kepedulian dari teman maupun keluarga. Secara umum, dukungan sosial dapat dilihat sebagai konsep yang bertolak belakang dengan perasaan kesepian. Oleh karena itu, besarnya dukungan sosial menjadi salah satu aspek penting yang dapat berkontribusi meningkatkan ketahanan individu terhadap kesepian seperti dibahas dalam studi (Stanculescu, 2016). 
Dampak meluasnya COVID-19 yang telah memobiliasi kedekatan keluarga dan mengembalikan fungsi-fungsi keluarga (Abubakar \& Alya, 2020). Ketika keluarga menyediakan perlindungan, perhatian dan kasih sayang yang dapat dirasakan sebagai dukungan emosional. Dalam konteks ini, temuan sebelumnya telah menegaskan bahwa sumbangan dukungan emosional lebih efektif dalam mengurangi kesepian secara signifikan (Hombrados-Mendieta, García-Martín, \& Gómez-Jacinto, 2013). Selain itu, kaitan keberfungsian keluarga dan kesepian pada remaja telah dikonfirmasi oleh Cendra (2012) dimana keduanya memiliki hubungan negatif. Artinya ketika keberfungsian keluarga semakin baik maka kecil kemungkinan untuk merasakan kesepian atau sebaliknya.

Hasil penelitian ini menunjukan tingkat kesepian remaja berada pada

\section{SIMPULAN}

Berdasarkan temuan dan pembahasan didapatkan simpulan bahwa tingkat kesepian remaja DKI Jakarta di masa pandemi COVID-19 ini berada pada kategori cukup tinggi. Hal ini perlu menjadi perhatian semua pihak agar tidak tidak merasuk menjadi kategori tinggi. Artinya, apabila kesepian remaja itu tinggi maka akan jadi permasalahan yang kompleks pada remaja tersebut dalam menata dirinya menjadi pribadi yang lebih baik dan tidak bermasalahah dalam kesehariannya. Pada kategori rendah kesepian ini diduga di sebabkan ada variabel lain yang dapat merubah respon kategori cukup tinggi. Lebih lanjut, upaya pengembangan dan meningkatkan ketahanan remaja terhadap kesehatan mental umumnya, khususnya kesepian harus tetap menjadi perhatian banyak pihak termasuk konselor. Kesepian sebagai reaksi situasi sosial bisa terus berubah bergantung pada ketersedian hubungan yang bermakna. Perhatian utama perlu dilakukan terhadap mereka yang lebih rentan mengalami kesepian seperti individu yang memiliki riwayat gangguan kesehatan fisik dan keluarga broken home. Di sisi lain, penelitian ini memiliki keterbatasan yaitu terbatasnya jumlah responden, sehingga dimungkinkan kurang merepresentasikan kelompok remaja yang lebih luas dan juga diharapkan penelitian ini juga diarahkan ke individu pada remaja.

remaja terhadap permasalahan yang terjadi. Oleh karena itu, diperlukan upaya penelitian lebih lanjut berkaitan pada aspek spesifik kesepian dan atau variabel lain yang dapat berkontribusi meminimalisir kesepian. selain itu, disarankan untuk menggunakan metode penelitian longitudinal sehingga dapat menguji perubahan-perubahan dari variabel dalam waktu yang lama.

\section{DAFTAR PUSTAKA}

Abubakar, A., \& Alya, N. U. (2020). Refunction Family during Covid-19 Pandemic (Study among Students of 
Anthropology UGM). Samarah: Jurnal Hukum Keluarga Dan Hukum Islam, 4(1), 151-178. https://doi.org/10.22373/sjhk.v4i1.7051 Azwar, S. (2019). Penyusunan skala psikologi (2nd ed.). Yogyakarta: Pustaka Pelajar. Barreto, M., Qualter, P., Victor, C., Hammond, C., Eccles, A., \& Richins, M. T. (2020). Loneliness around the world : Age, gender, and cultural differences in loneliness. Personality and Individual Differences, (January), 110066.

https://doi.org/10.1016/j.paid.2020.110 066

Cacioppo, J. T., Hughes, M. E., Waite, L. J., Hawkley, L. C., \& Thisted, R. A. (2006). Loneliness as a Specific Risk Factor for Depressive Symptoms : Cross-Sectional and Longitudinal Analyses, 21(1), 140-151. https://doi.org/10.1037/08827974.21.1.140

Cendra, A. (2012). Hubungan antara Keberfungsian Keluarga dan Kesepian pada Remaja Indonesia. Universitas Indonesia. Retrieved from http://lib.ui.ac.id/file?file=digital/20354 481-S-Andriani Cendra.pdf

Cosan, D. (2014). An Evaluation of Loneliness. In The European Proceedings of Social \& Behavioural Sciences (pp. 103-110). https://doi.org/10.15405/epsbs.2014.05. 13

Courtet, P., Olié, E., Debien, C., \& Vaiva, G. (2020). Keep Socially (but Not Physically) Connected and Carry on: Preventing Suicide in the Age of COVID-19. J Clin Psychiatry, 81(3). https://doi.org/https://doi.org/10.4088/ JCP.20com13370

Fiorillo, A., \& Gorwood, P. (2020). The consequences of the COVID-19 pandemic on mental health and implications for clinical practice. European Psychiatry. https://doi.org/10.1192/j.eurpsy.2020.3 5

Friana, H. (2020). WHO Umumkan Corona COVID-19 sebagai Pandemi. Retrieved July 6, 2020, from https://tirto.id/who-umumkan-coronacovid-19-sebagai-pandemi-eEvE

Gierveld, J. D. J., Tilburg, T. Van, \& Dykstra, P. A. (2006). Loneliness and social isolation. In A. L. Vengelisti \& D. Perlman (Eds.), The Cambridge Handbook of Personal Relationships (pp. 485-499). New York: Cambridge University Press.

Hammond, C. (2018). Who feels lonely the results of the world's largest loneliness study. Retrieved from https://www.bbc.co.uk/programmes/a rticles/2yzhfv4DvqVp5nZyxBD8G23/ who-feels-lonely-the-results-of-theworld-s-largest-loneliness-study

Holmes, E. A., Connor, R. C. O., Perry, V. H., Tracey, I., Wessely, S., Arseneault, L., ... Bullmore, E. (2020). Multidisciplinary research priorities for the COVID-19 pandemic : a call for action for mental health science. Lancet Psychiatry, 7, 547-560. https://doi.org/10.1016/S22150366(20)30168-1

Hombrados-Mendieta, I., García-Martín, M. A., \& Gómez-Jacinto, L. (2013). The Relationship Between Social Support, 
Loneliness, and Subjective Well-Being

in a Spanish Sample from a

Multidimensional Perspective. Soc

Indic Res, 114(3), 1013-1034.

https://doi.org/10.1007/s11205-012-

0187-5

Johns Hopkins University \& Medicine. (2020). COVID-19 Case Tracker. Retrieved July 6, 2020, from https://coronavirus.jhu.edu/

Luchetti, M., Lee, J. H., Aschwanden, D., Sesker, A., Strickhouser, J. E., Terracciano, A., \& Sutin, A. R. (2020). The Trajectory of Loneliness in Response to COVID-19, 2(999). https://doi.org/http://dx.doi.org/10.103 7/amp0000690.supp The

Menteri Kesehatan Republik Indonesia. Peraturan Menteri Kesehatan Republik Indonesia Nomor 9 Tahun 2020 Tentang Pedoman Pembatasan Sosial Berskala Besar dalam Rangka Percepatan Penanganan Corona Virus Disease 2019 (COVID-19) (2020). Indonesia.

Mushabi, S. (2020). Daftar 18 Daerah yang Terapkan PSBB, dari Jakarta hingga Makassar. Retrieved July 8, 2020, from https://nasional.kompas.com/read/202 0/04/20/05534481/daftar-18-daerahyang-terapkan-psbb-dari-jakartahingga-makassar?page $=$ all

Mushtaq, R., Shoib, S., Shah, T., \& Mushtaq, S. (2014). Relationship Between Loneliness , Psychiatric Disorders and Physical Health ? A Review on the Psychological Aspects of Loneliness. Journal of Clinical and Diagnostic Research, 8(9), 1-4. https://doi.org/10.7860/JCDR/2014/100
77.4828

Perlman, D., \& Peplau, L. A. (1984). Loneliness research: a survey of empirical findings. In Loneliness: $A$ Sourcebook of Current Theory, Research, and Therapy (pp. 13-46).

Putsanra, D. V. (2020). Arti Physical Distancing dan Social Distancing, Apa Perbedaannya? Retrieved July 10, 2020, from https://tirto.id/artiphysical-distancing-dan-socialdistancing-apa-perbedaannya-eHNf

Sønderby, L. C., \& Wagoner, B. (2013). Loneliness: an integrative approach. Journal of Integrated Social Sciences, 3(1), 1-29. Retrieved from http://www.jiss.org/documents/volum e_3/issue_1/JISS $2013 \quad 3(1) \quad 1-29$ Loneliness.pdf

Stanculescu, E. (2016). Perceived Social Support and Loneliness in Early Adolescents - a Path Analysis, 26(2), 109-121.

Tull, M. T., Edmonds, K. A., Scamaldo, K. M., Richmond, J. R., Rose, J. P., \& Gratz, K. L. (2020). Psychological Outcomes Associated with Stay-atHome Orders and the Perceived Impact of COVID-19 on Daily Life. Psychiatry Research, 289(May), 113098. https://doi.org/10.1016/j.psychres.2020. 113098

Victor, C. R., \& Yang, K. (2012). The prevalence of loneliness among adults : a case study of the united kingdom. The Journal of Psychology: Interdisciplinary and Applied, 146(1-2), 85-104.

https://doi.org/10.1080/00223980.2011. 613875 
WANTIKNAS. (2020). Akses Digital Meningkat Selama Pademi. Retrieved from

http://www.wantiknas.go.id/id/berita/ akses-digital-meningkat-selamapademi

WHO. (2020). Coronavirus disease (COVID-19) advice for the public. Retrieved July 6, 2020, from https:/www.who.int/emergencies/dis eases/novel-coronavirus-2019/advicefor-public

Zhang, Y., \& Ma, Z. F. (2020). Impact of the COVID-19 Pandemic on Mental Health and Quality of Life among Local Residents in Liaoning Province, China: A Cross-Sectional Study. International Journal of Environmental Research and Public Health Article, 17(7), 2-12.

https://doi.org/10.3390/ijerph17072381 